\section{William George Barnard}

William George Barnard was born on December 9. 1892, and died in St. Thomas's Hospital on December 20, 1956. He was the son of E. U. Barnard, a missionary, and his early years were spent in Tangier. Educated privately, he became a captain in the R.F.A. during the first world war. He received his medical education at the London Hospital, where he captained the rugby football club. Qualifying M.R.C.S.. L.R.C.P. in 1920, he proceeded to the M.R.C.P. in

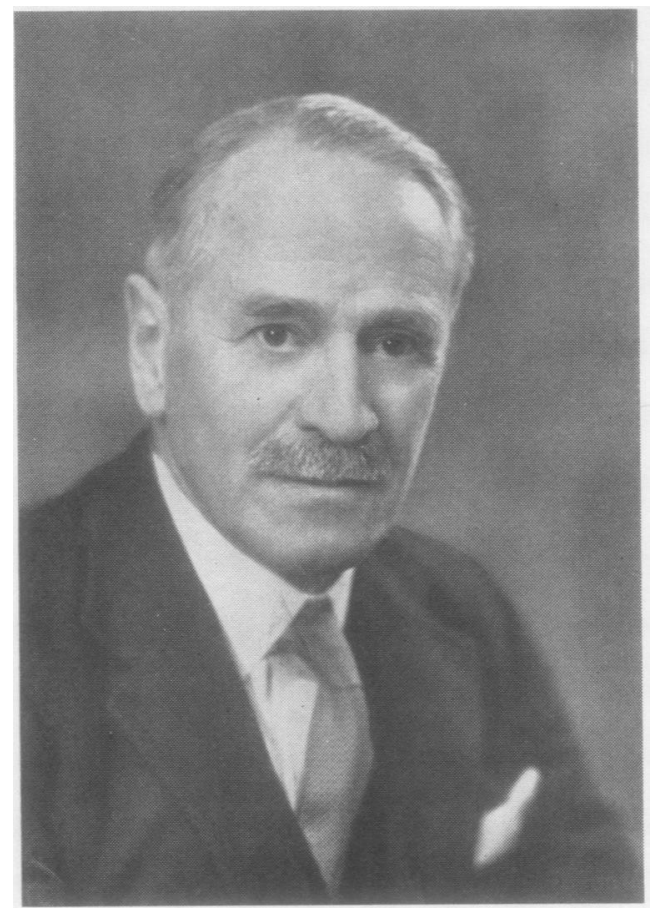

1931, and was elected F.R.C.P. in 1938. In the Coronation honours of 1953 he was gazetted C.B.E. He married Margaret Roscoe Osler in 1930, and their son Robin qualified at St. Thomas's Hospital in May, 1956.

Following qualification, Barnard spent some time as clinical assistant to surgical out-patients at the London Hospital, but soon became Assistant Pathologist, and then Junior Assistant Director of the Pathological Institute under Professor H. M. Turnbull. This step not only decided his future career but trained him in the exact and meticulous post-mortem technique which Turnbull had instituted.

In 1923 he left the London Hospital to become Pathologist to University College Hospital and Lecturer in Pathology and Curator of the museum in the Medical School. This move was of great importance. because it not only brought him into close daily contact with the inspiring personality of his chief. Professor A. E. Boycott, but with such intellectually active colleagues or pupils as Sir Thomas Lewis. Charles Bolton, Sidney Martin, Hedley Wright, G. W. Goodhart. C. R. Harington, C. Price Jones, V. R. Khanolkar, G. Payling Wright, G. R. Cameron, and C. L. Oakley. He also gained an insight into German pathology by spending six months during 1927 in the department of Professor Ludwig Aschoff at Freiburg. There is little doubt that it was during this time that Barnard acquired that profound respect for learning in general, and research in particular, that was so characteristic of him as an administrator in later years.

It is, therefore, all the more surprising that in 1931 he left the academic life he loved so much to become Consultant Histologist at the Archway Hospital. where he both acted in an advisory capacity to the group pathologists the London County Council had appointed about that time, and started to organize a pathological museum from the abundant post-mortem material coming into the department. But Barnard was destined to act on a wider stage, and his great opportunity came in 1939 when, following the death of S. L. Dudgeon, he was appointed Professor of Pathology at St. Thomas's Hospital Medical School.

The second world war broke out soon after, and for some years he, and what was left of his department, led a peripatetic existence in various parts of Surrey; but at the earliest possible moment he returned to the laboratories in the west wing of the Medical School, which had fortunately escaped un damaged in the extensive destruction that had visite St. Thomas's. He could now start the organization? of teaching in pathology and the staffing of the pathological services of the hospital, but this had barely got under way when, in the spring of 1947, Professor B. A. McSwiney, the Dean of the Medical School, died suddenly.

Since coming to St. Thomas's Barnard had shown that he had marked talent as an administrator, so that he was the obvious, indeed the only possible, choice as Dean. He held this post until the day of his death nine years later, and it is by his achievements during its tenure that he will be chiefly remembered.

One of his first duties was to carry through the complicated negotiations with the University on the one hand and the Hospital on the other, as a result of which St. Thomas's Hospital Medical School became. on the appointed day in 1948, a separate entity but a school of the University. At the same time arrangements had to be made for the large increase in the number of students, and for the entry of women into what had previously been an exclusively male establishment.

Of far greater importance was his realization that. until that time, the great opportunities for research in many of the London hospitals had been largely wasted, and that under their new constitutions much could be done to remedy this situation. He therefore set about a reorganization of the staff of the school so that research and teaching could become its main preoccupation, rather than the performance of routine duties for the hospital, or, what had previously been only too often the case, private practice. Com- 
pletely new academic departments of chemical pathology, bacteriology, and pharmacology were accordingly set up-while new professors of medicine, surgery, physiology, anatomy, and biochemistry were appointed as the previous holders died, retired, or obtained other posts. In this way, only two years after becoming Dean, he was in the fortunate position of having as heads of almost all his departments men who had not only been chosen by him but who were comparatively young, sympathetic towards his ideas, and fully trained to initiate and direct research.

Once appointed and their spheres of action clearly defined-Barnard was a stickler in such mattersthey were left alone and spared the time-wasting business of committees and administration as much as possible ; they were given the best assistants available, together with all the apparatus, space, and facilities that could be found. And in order to leave the academic departments free for research, the Dunn and Jenner laboratories, which are responsible for most of the pathological examinations, were made completely independent.

Under most circumstances, reforms of so sweeping a nature would have caused endless controversy or even bitter quarrelling, but Barnard's flair for administration was so marked that he was not only able to overcome opposition but avoided making enemies in the process. In this he was aided by his ability to prepare his case in every detail long before it appeared on the agenda paper. So thoroughly was every move studied, every source of criticism or opposition silenced or eliminated, that he was able to carry everything before him. In consequence, council or committee meetings with Barnard in the chair were little more than monologues by the chairman himself, reporting what he had done or was about to do. Even if one totally disagreed with his ideas, the wisest thing was to say nothing. Experience soon showed that, however wrong his ideas might appear to be, they were usually found to be right in the end, and that in any event argument was generally useless, for he knew far more about the question than anyone else.

With his newly constituted or rejuvenated academic departments functioning smoothly, Barnard was then able to devote his attention to other matters of importance, and, in course of time, new laboratories for the Departments of Medicine, Bacteriology, Chemical Pathology, and Pharmacology were built, the school itself was thoroughly overhauled, the Biochemistry Laboratory rebuilt, and several new lecture rooms provided. Shortly before his death he had set the necessary machinery in motion to remodel the Department of Anatomy, and to provide more space for the Departments of Pathology and Bacteriology.

If this were not enough, he became a member of the Senate of the University of London in 1951, and, shortly before his death, Dean of the Faculty of Medicine. With his previous record, it is virtually certain that, had he been given a few more years, medical education in London would, under his guid- ance, have altered very considerably. Along what lines the alterations would have proceeded one can only guess, for his plans were still unformulated, but it is impossible to conceive of Barnard as head of anything without leaving the mark of his personality.

In 1945 he was elected Treasurer of the Royal College of Physicians, and after the war was largely responsible for the renovation of the building and the provision of additional accommodation. He was an active member of many of its committees, but the duty he loved best was the organization of hospitality the College gave to the many international congresses that met in London, and the provision of the dinners held at the College in connexion with meetings of the Comitia. In order to fulfil his obligations properly, he became an expert on wines, saying on more than one occasion that he was only too well aware that his re-election as Treasurer year after year largely depended on his ability to dine and wine the Fellows adequately.

With all these activities-and only a tithe have actually been mentioned-Barnard had little time to devote to his own subject. Except for a course of lectures on general pathology, an occasional appearance in the post-mortem room, and help for friends with difficult sections, he was seen only infrequently in his Department. But he acted as an examiner in the Universities of London and Cambridge and at the Royal College of Surgeons in Dublin. A great many students should be thankful to him, for he hated to fail even the most obviously indolent.

$\mathrm{He}$ also attended meetings whenever he could, and was Secretary of the Medico-Legal Society for many years, a founder member of the Thoracic Society, and a member of the Association of Clinical Pathologists and the Medical Research Club. He was also elected President of the Section of Pathology of the Royal Society of Medicine, and his Presidential Address, delivered in 1944, is a masterly survey of the history and development of his specialty. During some of his busiest years he found time to attend the meetings of the Council of the Pathological Society of Great Britain and Ireland, and, even when sickening for his last illness, made the journey to the 50th anniversary meeting at Manchester, so that he could be present when the late Matthew Stewart was honoured on his retirement from the Editorship of its journal.

Despite his sympathy with research and experimentation, his own contributions to the literature of his subject were not extensive. But his paper (J. Path. Bact., 1926, 29, 241) on oat cell tumours of the mediastinum is of considerable importance, because he was one of the first to show that their origin is epithelial and not mesodermal, as had previously been supposed. He also wrote a small volume called Elementary Pathological Histology, which was first published in 1928, with a second edition in 1947 and a third in 1953 ; and, after the death of E. H. Kettle, he collaborated with Dr. A. H. T. Robb Smith in preparing the third edition of The Pathology of Tumours, which appeared in 1945. 
With broad shoulders and slightly under the normal height, he always held himself upright and with great dignity. Being fundamentally shy and sensitive, he was very difficult to know. Many thought him cold and aloof, but once the reserve had been penetrated he revealed himself as one of the kindest and gentlest of men. No matter how busy he might be, he was always prepared to put everything on one side and listen to one's story. The advice he gave may not always have been to one's liking. but he invariably saw the other point of view and produced very adequate reasons for the course of action he proposed. If it was possible for him to help, it was given freely. promptly, and without reservation.

Besides medicine, Barnard had many other interests. He played golf, being a member of the Royal St. George's Club at Sandwich and of the Royal Cinque Ports Club at Deal, and competed every year in the competition for the Treasurer's Cup at St. Thomas's. He loved gardening, and it must have caused him agony of mind when he was unable to work in the garden of the house at Chiddingfold he acquired only a month or so before his first attack in the spring of 1956. He also frequented sale rooms, and nothing delighted him more than exhibiting the first editions. furniture, or pictures he acquired in this way.

The last few months of his life were clouded by the realization that, although he still had two more years left before he need retire from his Chair and that his colleagues in the Medical School were prepared to allow him to act as Dean more or less indefinitely, it was improbable that he would live much longer. But he acted as though nothing had happened and literally died in harness. He had been a great Dean who had done much for St. Thomas's. Let this be his epitaph.

Ronald HaRe. 